\title{
"Having Walked Alongside You": A Conversational Exchange on Territory and Sound in Motion
}

\author{
MIGUELTZINTA SOLÍS and TYLER STEWART
}

\begin{abstract}
As two artist-scholars engaged in research-creation, our goal with this project was to enact a performance/discussion regarding settler-colonialism, sound, performance, and our relationships to land, body and time. During the initial "lockdown phase" of the COVID-19 pandemic in March 2020, we carried out a mediated conversation via WhatsApp voice memos, hiking towards each other along and across the Oldman River, then retracing the other's path back to our respective points of origin.
\end{abstract}

This collaborative project aims to decolonize the academic paper through a process which combines textual analysis, experiential learning, improvisational performance, and activated writing to ask questions of the relationships between sound, land, and colonial institutions. How does movement through space, and hearing the land, affect our experience of discussing texts? How is discussion informed by, say, the participants being separated (or connected) by a river? What richness exists in oral/aural exchanges that are lost in the textualizing process? What does it mean to move through occupied Blackfoot territory while discussing decolonialism?

The structure of this conversational exchange unfolds in loops rather than in the linear standard of academic writing. This "essay" was originally devised as an audiovisual text, but during further revisions, we continued our experimentations with form. The result has taken shape in dual outputs of both sound and text, each form containing affective and sensorial elements not found in the other, creating parallel yet distinct "texts." While this is an imperfect strategy for those who experience sight/hearing related disabilities, we also recognize that some sensorial experiences are untranslatable into the language of the other senses. We hope that we have encoded each experience of sound and text with enough richness for them to be enjoyed individually, and we invite those who can, to experience how the two forms play off of each other. 
To this effect, the form of this text focuses on the relationship between the content of our conversation and how it is presented, and between our conversation and the writers, artists and movements we have referenced. We also hope to emphasize our relationality with the land we walked through, the creators of the sounds we listened to, between us, the co-creators of this "text," as well as the relationship we create with you, the listener/reader experiencing it. As artists/writers/curators, it is a challenge to find alternative textual formats that appropriately reflect artistic research-creation methodologies while also satisfying the demands of academic knowledge dissemination. This collaboration explores the possibility for academic conversations to escape the confines of learning institutions into a space of praxis and embodied experience in motion.

Keywords: colonialism, landscape, performance, power, sound, space, time, experimentation with form

\section{ENTER SCENE.}

$T$ The date is Sunday, April 5, 2020 - approximately one month into the ongoing Covid-19 social gathering restrictions mandated across Canada. Migueltzinta Solis is on the west side of the Oldman River, at the University of Lethbridge campus, walking eastward. Tyler J Stewart is on the east side of the Oldman River, walking westward from his home in the London Road neighborhood. As they walk towards each other, voice messages, video clips, and photographs are sent back and forth in a conversation mediated through the WhatsApp platform on their mobile phones. This is a transcript of that conversation, with additional footnotes and citations added intext as mentioned within their dialogue.

\section{$\{4: 59\}$ [Birds chirping]}

[Feet walking]

[Water sounds]

[Canadian geese honk faintly in the background as they migrate northward] 
[Vehicles pass by loudly as the pedestrian signal beeps. Vehicle sounds fade away]

\{6:00\} TYLER: Hey Migueltzinta, it's Tyler. I am at the corner of Scenic Drive and 4th Street South. Aaaaaand I hear a lot of car noise. Which has now dissipated.

I can see the university and I'm gonna wait until I see you in the little UHall slot, or breezeway, as I suppose it's more appropriately called.

MIGUEL: Hey Tyler, I am [laughter], I jumped the gun and went down to where the storm drain, where the university storm drain dumps out into the river. I saw some interesting things on the way down here. It's really, really quiet. I don't really know, like, if I was here on a Sunday at school, pre-pandemic, would it be the same quiet? Is the quiet I feel emanating from the university just my own, like, is it a quiet I'm hearing with my ears, or is it a quiet that I just know because of what's going on?

$\{7: 40\}$ TYLER: I appreciate that you already brought in the idea of the affective listening experience, and on the way over here I was thinking about how we can listen with our feet, just in the difference between walking on concrete or gravel and now what you can hear me walking on a grass/mud path.

[Footsteps walking on grass/mud path] ${ }^{1}$

MIGUEL: There's a lot of birds out.

[Footsteps on a hard surface]

MIGUEL: It's not as icy as I thought it would be.

[Footsteps move to a softer surface $]^{2}$

\footnotetext{
1 "Hearing is basically a specialized form of touch. Sound is simply vibrating air which the ear picks up and converts to electrical signals, which are then interpreted by the brain. The sense of hearing is not the only sense that can do this, touch can do this too. If you are standing by the road and a large truck goes by, do you hear or feel the vibration? The answer is both." (Glennie 2015, n.p.).

2 "Deafness does not mean that you can't hear, only that there is something wrong with the ears. Even someone who is totally deaf can still hear/feel sounds" (Glennie 2015, n.p.).
} 
MIGUEL: I think I'm noticing a lot of new nests too. ... okay. I'm coming up onto the breezeway.

\{8:58\} TYLER: (shouting) CAN YOU SEE ME NOW? CAN YOU HEEEEEEEAR ME?

MIGUEL: [laughter] I totally heard you. It was very faint.

[whistling]

TYLER: I don't think I heard you whistling, but some other people on this side of the river definitely responded to my ... hails. Now that I'm down in the valley, in this gully, away from traffic, you can notice the difference, but still hear this background flat texture of road noise behind me. It's interesting to think of the directionality of how we hear and how it's mostly coming from below me right now, from my feet, and behind me from the distant road noise. Which direction do we normally listen to? Is there a general direction that occupies most of our waking listening moments? ${ }^{3}$

\{10:18\} MIGUEL: I'm gonna start walking down and see if you can ... I don't trust my shouts to actually be that loud. With my 'tran' voice and all that. [laughter] But I do have a trick up my sleeve, but I think I gotta get a little closer first. So I'm walking down from the breezeway on the trail towards the river. Whoa, I almost fell! [laughter] It's very ... it's definitely slippery here.

[Walking and wind sounds]

TYLER: As we've previously discussed, it's likely that the white male ear is the least likely to hear a trans person's voice, but I'd like to think that my listening is a little more attuned than the average white man's ear. ${ }^{4}$

\footnotetext{
3 "There are fewer distant sounds in the city, just as there is less distant viewing. The loss of distant hearing is one of the most significant changes in aural perception in history. The urban environment has compressed acoustic spaces and confused directionality, making it often difficult or impossible to locate sources" (Augoyard 1995, xv).

4 "Liana Silva argues that loudness remains a male privilege in American culture, so women who wield loud voices are dubbed lower class and 'noisy, rude, unapologetic, unbridled.' ... In a society bound by
} 
MIGUEL: Yeah definitely. I'm feel like, I'm curious to see if you will hear my prosthesis that I brought today. [chuckles] My voice, my sound, yeah I guess - my voice prosthesis? But yeah, I feel like, I think the question of direction ... I've been thinking a lot about that, especially now as the pandemic is kinda like, it's just kinda re- - I dunno - reconstructing our relationships to time and production, and productivity, and how that is the stuff we've been talking about in class, in terms of the decolonization of very basic ways of being in the world that we completely take for granted. And so I think that the direction we are often walking towards is the future, to the next thing, or the place you need to be. And so it's like you walk ... the present is something you walk through, so the direction we're walking through in the present is into the future beyond, like out of it, basically.

\{12:55\} [Water splashing sound. Intermittent. Like water being poured out of a bucket in splashes.]

TYLER: I'm down in this really narrow section of the gully, and as I descended about a three or four meter little pitch, you could feel the difference in sound, like, feel it drop away. This also reminds me of Sara Ahmed and how we're oriented and how we're aligned in certain ways. How something can pull us in a certain direction of being and orient our listening in a particular way. ${ }^{5}$

[Walking sounds, sounds mushy]

MIGUEL: I'm also now down ... no, I'm not quite in a gully, I'm in the bottom of one of the coulees that leads down from the breezeway down to the river. I just got to the part where the sides are steep, and yeah, the acoustics are also really different. I also thought it was interesting how I have this memory of trying to explain playing blindman's bluff with my siblings, or my cousins or something, and trying to explain to them that I could hear an open door.

sonic color lines and glass ceilings, 'loudness,' Silva contends, 'is something racialized people cannot afford"” (Stoever 2016, 23).

${ }^{5}$ The ways in which our social structures are aligned determines which voices are amplified and which voices are silenced, and how we orient ourselves individually can determine our understanding of the world. Sara Ahmed argues that compulsory heterosexuality acts as a form of repetitive strain injury, in that through the repetition of enforced actions which constrain the body, "our body takes the shape of these repetitions; we get stuck in certain alignments as an effect of this work" $(2006,28)$. In what ways have our ears been shaped by heteropatriarchy and settler-colonialism? 
TYLER: That brings up an interesting point around the language of listening, ${ }^{6}$ like, that you might not be able to listen attentively without a language to understand it, like a psychological language I suppose it would be? In order to translate, or comprehend, or make meaning, most importantly, of what you're actually listening to, ${ }^{7}$ and how that also relates to the difference between hearing and listening, which I'm always on about, ${ }^{8}$ in terms of how we're always hearing tons of stuff, but we haven't had the skills or been equipped with the skills to actually listen to what we're hearing.

\{15:36\} [Water sounds, like someone playing in a puddle or an oar in a lake.]

MIGUEL: I just stopped to pee, which I did not take the audio of, that seemed a little personal. [laughter] That's a different performance. [laughter] But it made me think of - this is very related - it made me think about how when I was first coming out as trans and trying to figure out how to pass as male, I remember - this would have been in 2009 or so, 2010 - and I remember going on this one thread where there was this trans guy saying - it was really intense, he was really intense - he was going into all these insane details of what you should and should not do in order to pass as a man, as a cis man, and one of the things he said is that you should never piss in a public washroom because men ... because the sound of, like, a female body peeing is different than a male body peeing, and that men would be able to tell, and so they would 'out' you. They would out you as trans, because they could hear that your pee was different. And I was like no one ... men don't pay attention to that. You wouldn't pay attention to that unless you were like, actively trying to out F2Ms or something like that, so I thought ... I just thought that was really fascinating, and you know, but you know, maybe. . I mean, clearly, that trans man had that ear. That ear for passing as a man.

6 "On the one hand, we can simply hear an echo as an additional sound (sonic perception) in the same way that we hear the original hand clap (sonic event). On the other hand, we can interpret the echo as a wall (passive acoustic object). The echo is the aural means by which we become aware of the wall and its properties, such as size, location, and surface materials, The wall becomes audible, or rather, the wall has an audible manifestation, even though it is not itself the original source of sound energy. We can 'see' with our ears" (Blesser 2006, 2).

${ }^{7}$ For an excellent reference guide to the sonic lexicon: Augoyard, J.F. (1995). Sonic Experience: A Guide to Everyday Sounds. McGill-Queen's University Press.

${ }^{8}$ Roland Barthes described this difference in that "hearing is a physiological phenomenon; listening is a psychological act," (1985, 245), while Lisbeth Lipari further advances this notion and uses a phenomenological lens to consider "listening as a way of being, which moves us toward an ethics of attunement-an awareness of an attention to the harmonic interconnectivity of all beings and objects" $(2014,2)$. 
\{17:39\} TYLER: [shouting] HELLO!

MIGUEL: [whistling, long and loud, then in short melodic bursts]

TYLER: Jennifer Stoever has this book called The Sonic Color Line, which is also a theory of how sound is an embodied experience that also creates racialized experiences of sound, ${ }^{9}$ which I think applies in the same way to gender, or gendered listening as well. This connects directly to this idea of the 'whiteness of hearing' concept that I'm trying to elaborate, that kinda posits that hearing through a whitened ear is kind of constructed as the natural or neutral way of hearing things.

Holy shit, that's a big hawk!

\{18:55\} MIGUEL: [calling out] I can hear you! ... THIS IS AS LOUD AS I CAN SHOUT!

[harmonica plays melodically in a high register]

TYLER: I knew your prosthesis was going to be the harmonica!

MIGUEL: Ah, you guessed right. [laughter] I can actually hear you speaking into WhatsApp from here. Can you hear me speaking into WhatsApp from here?

TYLER: [laughter] Definitely.

TYLER: My phone is already down to $35 \%$ battery, so I'm gonna keep walking towards the bridge now.

MIGUEL: Okay that sounds good, yeah, we can think about theory as we walk and be quiet, and then we can check in.

\footnotetext{
9 "The sonic color line is both a hermeneutics of race and a marker of its im/material presence. It enables listeners to construct and discern racial identities based on voices, sounds, and particular soundscapes-the clang and rumble of urban life versus suburban "peace and quiet," for instance-and, in turn, to mobilize racially coded batteries of sounds as discrimination by assigning them differential cultural, social, and political value. The sonic color line produces, codes, and polices racial difference through the ear, enabling us to hear race as well as see it. It is a socially constructed boundary that racially codes sonic phenomena" (Stoever 2016, 11).
} 
[footsteps in puddles, damp grass]

TYLER: I just saw a fucking coyote run like 50 yards in front of me through the bush!

[sound of Northern Flicker calls]

\{20:28\} MIGUEL: So in, what's it called, Settler Commons Sense, the Mark Rifkin book that I was reading for this, the chapter on Walden, it's called, I believe the chapter is called "Loving Yourself Like a Nation." So this idea that nature is wrapped up with ideas of innocence and naturalness, and Eden-esque notions that are tied in together with erasure of Indigenous communities ${ }^{10}$ and the idea of the savage, whether the bloodthirsty savage or the noble savage, ${ }^{11}$ and how Walden presents nature as this place where we can go and in a way become ourselves without the narratives of capitalism and production and industrialization. And so Rifkin is looking at that and saying that yes, wilderness does provide a place to find oneself and learn to love yourself - this is a very basic summary of it - but also it shouldn't mean that nature should equal "without people." ${ }^{12}$

10 "While Thoreau forswears possession itself, his oppositional queer conception of personhood also takes shape around the voiding of Native geopolitics in New England, casting nature as immune from political contestation and the eruption of competing sovereignties. Furthermore, that sense of a place within the state yet distinct from its legal geography arises out of and gains momentum from the ongoing legal representation of Native presence and territoriality as an anomaly" (Rifkin 2014, 93-94).

11 "Becoming conscious of the phenomenology of settlement, and the implicit ethics of exceptionalization and occupation that it enacts, involves a relinquishing of the notion of a sovereign selfhood existing in a place apart. Instead, the celebration of waste and of unproductive activity, of a break from the quotidian protocols of the state and its logics of property and citizenship, opens onto a recognition of enduring Native presence within contemporary political economy. Such an awareness further highlights the effaced history of imperial superintendence and displacement-the management, translation, and erasure of Indigenous sovereignties-that provides the enframing condition of possibility for the sense of settler escape into the wilderness" (Rifkin 2014, 139).

12 "In a journal entry on September 1, 1842, Nathaniel Hawthorne observes of Henry David Thoreau that he is 'inclined to lead a sort of Indian life among civilized men,' noting in particular 'the absence of any systematic effort to livelihood.' He suggests 'Indian life' entails being outside of the capitalist economy, existing in some space other than that of 'civilized men.' Native peoples in New England in this period, however, very much were enmeshed in the political economy of indenture, debt, itinerant seasonal labor, diaspora in search of wage work, and an ongoing land loss due to nonnative agricultural and logging interests" (Rifkin 2014, 91). 
It's funny how we think of nature as being quiet. I think we've talked about that before. It's really not very quiet at all. Is that you back on the bank there? Ok good, I'm glad you're not too far.

TYLER: That makes me think of the idea of nature being quiet is almost kinda connected to the idea of domesticity, or domestication of nature, and this nature-culture divide ... that we exalt quiet nature, and loud nature is somehow bad, or we're unable to find beauty in the loudness of nature in the same way that a quiet construct of nature is appreciated. We want nature to be quiet, we don't want it to speak up, we don't want it to say things we don't want to hear, which makes me think about not only the way that we hear and/or listen to nature, but the way that nature speaks, and in which voices does it speak, but also then how nature itself can listen. How does nature hear us? ${ }^{13}$ What are we saying to nature through our actions and through ${ }^{14}$ our sounds, and how does nature hear that? Does nature listen to us, or does nature simply hear us, in that way of hearing being a physical act, and listening being more of a psychological experience or action? ${ }^{15}$

\section{$\{24: 07\}[$ road sounds]}

TYLER: I'm under the Whoop-Up bridge. There's an interesting architectural feature, or an acoustic architectural feature, which is the gap between the westbound and eastbound lanes as a bit of an acoustic crevice.

\footnotetext{
13 "[Tlingit and Athapaskan] oral traditions frame glaciers as intensely social spaces where human behaviour, especially casual hubris or arrogance, can trigger dramatic and unpleasant consequences in the physical world. In other words, Tlingit and Athapaskan oral traditions explore the connections between nature and culture as carefully as early exploration projects tried to disentangle them" (Cruikshank 2005, 11).

${ }^{14}$ Dylan Robinson asserts that we must focus on the relationships created through listening to understand "the space of sonic encounter as a space of subject-subject relation" that also considers sound itself as a living entity with a subjective agency that should be respected as well (2020, p. 15). Rather than the unidirectional exchange of settled listening, Robinson argues in favor of an affective approach to listening that might open up sovereign spaces of sonority, encouraging a "transformative politics of listening that are resurgent in their exploration of Indigenous epistemologies, foundations, languages, and sensory logics; or, ones that are decolonial in their ability to move us beyond settler listening fixations" (p. 38).

15 "[. . . ] there is a tangible physical world out there that sometimes affirms but often mocks the representations we design to constrain it" (Cruikshank 2005, 7).
} 
MIGUEL: That makes me think about the science hoax about the water molecules, that if, you like, cussed at the water molecules they would be ugly, and if you played the water molecules Mozart they would be pretty. ${ }^{16}$ I don't know if it was the crystals or the molecules. I can't remember exactly, but it was interesting because everyone kinda latched onto that. A lot of people really latched onto that and used it as ... I don't know how many frickin' academic conferences I went to, where in a presentation it was used as some kind of metaphor. I was always like 'I don't know about this,' and the reason was because I found it insulting, because the thing was about 'oh the energy,' which is very subjective in a particularly human way, to say that 'oh you know, of course Mozart is going to produce beautiful patterns in the water molecule or whatever,' and you know. Of course, in my work, what if you were cussing at water erotically? ${ }^{17}$ I don't know, you know, it's just a very human perspective, and a particular kind ... you know, you could say ... what canon is Mozart coming out of? But I also feel like it says something about our desire for nature to hear us, right?

TYLER: I think what you were talking about there, maybe we're not talking about the same thing, but what's called "cymatics," ${ }^{18}$ I believe is the name, where you play a frequency of sound underneath some kind of surface ... a drum skin membrane, or a piece of glass, or a panel with sand on top, and different frequencies arrange the sand, or whatever the material is ... usually it's sand on top, into different, you know, auralized patterns. So the sound is what creates the visual patterns.

MIGUEL: Standing under the Whoop-Up bridge now, too. I was just thinking it's interesting how the landscape here is really shaped by the sound of Whoop-Up Drive ... like, one locates oneself according to that sound, but we don't really talk about it, say,

\footnotetext{
${ }^{16}$ His ideas popularized by the 2004 film What the Bleep Do We Know?, Masaru Emoto posited that speaking to water "positively" made its crystals aesthetically pleasing and symmetrical while speaking to water "negatively" made them "ugly." His book The Hidden Messages in Water has since been dismissed as pseudoscience.

${ }^{17}$ Migueltzinta's MFA thesis work Landscape is My Sir (2018-2019) revolved around a leather daddy seeking an S/M relationship to land, and included performances where the leather daddy persona, Chico California, spoke erotic profanities and perversities to "natural" sites and objects within the site, as well as physically beating, flogging and talking smut to colonially charged ephemera such as colonial travelogues and historical Albertan textbooks from the 1970s.

${ }^{18}$ Hans Jenny first developed the term cymatics his 1967 book Cymatics: The Study of Wave Phenomena, but this technique of manipulating sand on metal dates back to Ernst Chaldni's experiments in 1787. While sound artists often use this approach simply on a surface level, Lisbeth Lipari notes that "for Jenny, cymatics demonstrated that sonic vibration was the primordial organizing principle of all life" and that "cymatics illustrates how synchrony is not a stillness but movement, and that holistic perspective offered by cymatics can provide deep insights into the interconnectivity that not merely surrounds, but, in fact, is us" $(2014,156)$.
} 
as much as how we talk about how the university, visually, is a landmark, or shapes the landscape. ${ }^{19}$ I always felt that the train is really interesting in that sense, because during the day I can't really hear it much, but at night when it's quiet, or if the wind is blowing in the direction of my house, then I can definitely hear it.

\section{$\{28: 07\}$ [car passing by]}

[harmonica blows a mournful sound, notes in the low register sounding slowly]

[faint sounds of footsteps, and a car whipping, mingling with the harmonica mimicking a train whistle blowing past]

TYLER: What you're talking about is what Murray Schafer ${ }^{20}$ calls the soundscape, and Barry Truax refers to more as an acoustic community. The actors in a community shape how it sounds, and to a large extent that is shaped by human sounds, and we complain about the sounds we don't like, but at the same time we're the ones that have installed those in our community. ${ }^{21}$

Murray Schafer also talks about how the materials of our world shape our experience of the acoustic community. How materials like wood, metal and glass used to be more

\footnotetext{
19 "In the very long view, the shift from orality to literacy-according, most famously, to Walter Ong and Marshall McLuhan-gradually transformed people from engaged speakers and listeners into silent scanners of written words, isolated readers in the linear world of texts. The print revolution abetted this shift. Words became printed objects more than breathed speech, things to be seen rather than voices to be heard" (Schmidt 2003, 42).

${ }^{20}$ R. Murray Schafer popularized the term 'soundscape' in his 1977 book, The Soundscape: Our Sonic Environment and the Tuning of the World. The soundscape refers to the natural acoustic environment, and its study is often referred to as acoustic ecology. It can be criticized for often retaining a notably Eurocentric, masculine perspective.

21 "The acoustic community may be defined as any soundscape in which acoustic information plays a pervasive role in the lives of the inhabitants (no matter how the commonality of such people is understood). Therefore, the boundary of the community is arbitrary and may be as small as a room of people, a home or building, or as large as an urban community, a broadcast area, or any other system of electroacoustic communications. In short, it is any system within which acoustic info is exchanged" (Truax 1984, 57).
} 
common, and how the acoustic community is now, to a great extent, shaped by what he calls the "dull thud" of plastic. ${ }^{22}$

I was thinking also earlier about the train, and also thinking back to your performance last night, ${ }^{23}$ and the building of the railway, and in a way how that is like a soundmark. I think this is one of Schafer's terms too. A soundmark is an identifying sonic feature of a soundscape, or an acoustic community, and thinking of the train as a colonial soundmark. The blaring of the horn announcing the impending progress and expansion of the colonial imperative. If I remember correctly, I think it was the CPR, Canadian Pacific Railway, whose whistle is tuned to an E-flat minor triad. ${ }^{24}$ So like, a minor chord is generally thought to be a darker, sad type of sound, but also interesting that it's E-flat which is, from a musical standpoint, an interesting choice of key, and I wonder if there's some kind of compositional theory behind that choice, or if it just is what it is.

Now I'm also thinking about how the harmonica is often compared to a train in musical senses, especially in the blues. Thinking of how playing the harmonica 'to' the landscape, as a musical mode of communication, could be wrapped up in a language of colonialism to a certain extent? There's something there to unpack in terms of how a harmonica could fit into your ideas around performing to the land, or performing for the land as a sentient being, as a lover, but then in another sense, thinking of how you can perform with the land, so that it's actually back to ... like I was saying about how the land can speak and listen ... that you can improvise, or you can have a musical conversation with the land as an active participant in a musical composition, or in a jam session, or however you want to describe that, in a melody of sorts.

\{32:41\} MIGUEL: This morning I was totally wondering about the history of the harmonica, because I was thinking about that too, and because, like, it's a sound that's so related to the idea of the train and the idea of the west. The way it is, you know, how we were briefly talking about Ennio Morricone as a composer. His soundtracks have a lot of harmonica layered into them. I'm forgetting which film this was in ... oh god, I

\footnotetext{
22 Schafer notes how common materials affect the soundscape, where previously common materials such as wood or glass had more resonance in comparison to "plastic-the all-purpose modern material of peerless pudency, with a voice like a thud" $(1977,164)$.

${ }^{23}$ Oh My Darlin' Quarentine, a virtual live-cast performance, April $4^{\text {th }}, 2020$. A segment of the performance featured imagery from the building of the CPR, and a cowboy persona named Thirstin West who sold his lover (his boyfriend was made out of toilet paper.)

${ }^{24}$ Schafer notes that the CPR whistle's E-flat minor triad is a "deep and haunting whistle" that provides the unifying soundmark of the nation. More than any other sound it is uncounterfeitingly Canadian" $(1977,82)$. People from Indigenous nations living in the late 1800s/early 1900s when the railway was built (and today), might not agree with his unifying sentiment.
} 
can't remember ... it's one of the Italian westerns, but the narrative is like ... the two men are facing off at the end of the movie, and one of them has a flashback to his father being, like, hanged, and the character's a boy, and they balance the dad on his shoulders with the noose around his neck, and the villain comes and puts a harmonica into this mouth, and then the boy collapses and the dad hangs. ${ }^{25}$ So then of course, it flashes back to the present, and he recognizes it's the man with the harmonica, and then they have their shootout [laughter]. I'm interested in the harmonica for that reason, and then one of the readings that influenced that performance, was Margot Francis's book Creative Subversions, ${ }^{26}$ and there's a chapter about western expansion and the role of the railroad in that, so I'm really interested in this thing about the E-flat sound of the train whistle. Yeah, why did they choose that? Why is that how they tuned it, and what did it mean to different people? To hear the train whistle during its construction and during its initial use, like, what did it mean to be from one of the nations whose land was disrupted during that construction? What did it mean to begin to hear the train whistle? ${ }^{27}$

I'm now on the east side of the river, and I'm walking towards ... I just crossed the road that goes up from the fort, and I'm walking towards the railroad tracks, or the bridge, and I'm thinking about how there's just so much ... it's amazing how the railroad is this center from which all these different interesting histories spread out. ${ }^{28}$ Even the relationship between imprisonment and labour, and the railroad, and its history of chain gangs, and the different music histories that are tied up with that too. You know better than I, but there's a lot of blues roots tied up in train songs and chain gang songs,

${ }^{25}$ Once Upon a Time in the West, Sergio Leone, 1968. Curiously, the soundtrack for the film, by Ennio Morricone was composed prior to filming so the actors could have it played while they acted, an interesting metaphor or microcosm of the ways in which Wild West mythologies are produced.

26 "The 'philosophy' of railways was bound up with a sense of continental entitlement characteristic of both the Canadian and American national missions. For if Canada's claim to the immense north and western territories was, on its own, an audacious act of political imperialism, then it was the railway that provided the essential technology to bring the west into this emerging Dominion [. . .] Indeed, from a Foucauldian perspective, the railway symbolizes the decentered strategies of imperial rule and is an emblem of what Cole Harris calls 'the capillaries of colonial appropriation.' Thus, it was the railway that enabled both the United States and Canada to secure control over the western territories" (Francis 2011, 62).

27 "[. . . I]t was the railway rather than the military, that tipped the balance of power with Indigenous peoples and made the outcome of the struggle for the western territories inevitable. Thus, for many, the CPR was a crucial symbol of the disciplines of white appropriation and control" (Francis 2011, 66-67).

${ }^{28}$ Schafer describes the sound of the train as a key "soundmark" of Western expansion, but hears this as a productively resonating sound, in that "the train's whistle was the most important sound in the frontier town, the solo announcement of contact with the outside world" (Schafer 1977, 80). His settlercentric notion of the soundscape fails to consider how First Nations peoples would have interpreted the sounds of the railway more as a destructive and oppressive tone, rather than a productive sonic signal. 
right. I think that's all really, really fascinating. I think it's so interesting how ... I'm so curious about what the role of trains is now, when there's all these issues around transportation, and the airline business is dying, but then also the way the railroad is appearing in the Wet'suwet'en demonstrations, ${ }^{29}$ and the different other blockade demonstrations that have happened in solidarity with the Wet'suwet'en demonstrations.

I'd be curious if your research about power and sound looked into that or touched on that, about the train whistle and its relationship to power.

TYLER: That makes me think back to research around sound and power, but also relating to industrial sound and its economic significance, ${ }^{30}$ like it's profitable sound, versus the silence of poverty.] That idea of sound's power in that way too, like the power of sound as an economically productive sonic force.

I seeeee yoooooouuuuu.

$\{38: 38\}[\ldots]$

MIGUEL: So I am now sitting here with Tyler.

TYLER: Hi.

MIGUEL: Tyler's phone ran out of battery, so he came to the Helen Schuler Nature Centre and plugged into the wall on the outside, and now I have come and met him here, and we're going to keep talking in person, face to face, which is really strange. We are on day ... I'm on day 22 of quarantine, I think? Is that about where you're at?

TYLER: Is today Saturday? Sunday. Yeah, 24 maybe? Something like that.

MIGUEL: So we're almost at about a month, and we're forgetting how to interact with people that are not our significant others. [laughter]

\footnotetext{
${ }^{29}$ For more details on this see: https://www.aptnnews.ca/national-news/sit-ins-and-demonstrationscontinue-in-support-of-wetsuweten-hereditary-chiefs/ and https://globalnews.ca/news/6560125/timeline-wetsuweten-pipeline-protests/

30 "[. . M] odern western civilization is technically oriented and founded on loud industries, [and] has come to associate noise with the positive values of productivity and growth. A working machine makes lots of sound, cash register noise means profits. Silence means suffering" (Scollon, in Foy 2010, 80).
} 
TYLER: The thing I was thinking about was, just to insert Glen Coulthard into the conversation a bit just to have some other reference points, of writers and stuff ... I was thinking earlier about how the land can speak, and the land can listen, and then I was thinking about the idea of recognition, ${ }^{31}$ and if we think of the land as a sentient actor... I was thinking about naming because part of what colonialism does is rename things, right? $^{32}$

MIGUEL: Yes.

TYLER: So I was saying before about how a whiteness of hearing makes it so that is the natural, purportedly natural, neutral way of hearing things through the 'colonial ear,'33 let's call it. So is there a requirement to properly recognize the land, ${ }^{34}$ or aspects of the land in non-colonial ways? I'm thinking generally about how we refer to the City of Lethbridge, how we refer to Oldman River, how we have erased Indigenous names and Indigenous identities, both, and if that is a strategy, to address that erasing, is to reclaim those Indigenous identities, or the way that we conceptualize "non-sentient beings," 35 like the river, or the earth, or a piece of land, or ... if ... in Coulthard's paradigm, ${ }^{36}$ he would just be like, no, you're just looking for recognition. You're just looking for the colonizer to affirm your way of believing so that it has value. If he would say we don't need to worry about renaming things, because Indigenous people are still going to

31 "Negatively, it strives for the dissolution of native societies. Positively, it erects a new colonial society on the expropriated land base-as I put it, settler colonizers come to stay; invasion is a structure not an event. [. . . Settler colonialism destroys to replace" (Wolfe 2006, 388).

32 "Indeed, depending on the historical conjuncture, assimilation can be a more effective mode of elimination than conventional forms of killing, since it does not involve such a disruptive affront to the rule of law that is ideologically central to the cohesion of settler society" (Wolfe 2006, 402).

${ }^{33}$ Dylan Robinson describes this as "hungry listening," a modality focused on extraction and consumption, which points to more than just a mode of hearing, but also outlines a form of settlercolonial perceptual orientation (2000, p. 2-3). Hungry listening seeks to capture information, establish ownership over 'facts,' or focus one's attention; becoming a civilizing sensory paradigm which disciplines the ear into Eurocentric perspectives on the world, and ignores Indigenous cosmologies. 34 "The land is humiliated, and since Indigenous Peoples and our knowledge is part of the land, we all suffer" (Simpson 2014, 379).

35 "[. . . I I offer the listening ear as the ideological filter shaped in relation to the sonic color line. The listening ear represents a historical aggregate of normative American listening practices and gives a name to listening's epistemological function as a modality of racial discernment. An aural compliment to an interlocutor of the gaze, the listening ear is what Judith Butler calls "a constitutive constraint": a socially constructed ideological system producing but also regulating cultural ideas about sound" (Stoever 2016, 13).

${ }^{36}$ Coulthard, Glen Sean. 2014. Red Skin, White Masks: Rejecting the Colonial Politics of Recognition. University of Minnesota Press. 
recognize them for what they really are, that the river is Napi, and things like that. That it doesn't matter if settler people have that same recognition or not?

\{42:17\} MIGUEL: So Mike Bruised Head was doing a whole thing ... you know Mike Bruised Head, right? Yeah, he was doing a bunch of research about the Blackfoot names. ${ }^{37} \mathrm{He}$ was saying there were places he couldn't find the Blackfoot names, so he had this kind of question, both on the literal level, and on the more theoretical level ... wondering where did the names go? Where are they? Which I really like, because it's a question of what is the knowledge that is lost in the un-naming of places. ${ }^{38}$ What you're saying at the end there, about settler innocence that is in Tuck and Yang, where they're talking about offering up incommensurability instead of reconciliation. ${ }^{39}$ I think it's really interesting to think about, when I'm placing myself in these questions, I think about how I'm not white, [laughter] but I'm not Indigenous either. ${ }^{40}$ So then I'm like okay, what colonial systems do affect my ear, and what do I have that is not that, and what are the ways in which I might give more time to the Other? I don't know. If knowledge is in the names, and in the language, right, and in the hearing of the language, then even just replicating the language alone doesn't actually guarantee the knowledge to come with it.

TYLER: Part of it is, you know, from a critical point of view, Coulthard would say something like 'oh yeah, start naming all the places Blackfoot names again, but what does that do?' That's just a small inclusionary element, that is an act of colonial hearing, where it's like, oh yeah, we hear your places now, yeah, we'll call them by those names, but we won't fundamentally change the structures that continue to perpetuate other things. Besides, like, is it more important to destroy systemic inequality, or is it more

\footnotetext{
37 "I've found 18 [Blackfoot] names so far and they all have a meaning. They're not named after British monarchy, kings and queens or whatever. These are the true names of that geographical area" (Bruised Head 2018, "Obtaining Indigenous Knowledge: Really Knowing from Place").

${ }^{38}$ Mike Bruised Head calls the process of replacing Blackfoot place names with colonial names "cultural, language genocide," (Bruised Head 2018) an act of conquest which erases the Indigenous knowledge embedded into the Blackfoot place name.

39 "Settler moves to innocence are those strategies or positionings that attempt to relieve the settler of feelings of guilt or responsibility without giving up land or power or privilege, without having to change much at all. In fact, settler scholars may gain professional kudos or a boost in their reputations for being so sensitive or self-aware. Yet settler moves to innocence are hollow, they only serve the settler" (Tuck \& Yang 2012, 19).

40 "This discussion will likely cause discomfort in our settler readers, may embarrass you/us or make us/you feel implicated. Because of the racialized flights and flows of settler colonial empire described above, settlers are diverse - there are white settlers and brown settlers, and peoples in both groups make moves to innocence that attempt to deny and deflect their own complicity in settler colonialism" (Tuck \& Yang 2012, 19).
} 
important to have people use Blackfoot names? Well, they're both important, but the colonial ear would be like, ${ }^{41}$ oh yeah, we hear you, we'll change the names, we'll make efforts to really hear what you're saying, but don't listen to the more deep-seated issues of inequality and other concerns, besides just hearing that voice, the name of the thing.

\{45:53\} MIGUEL: In California, there's a significant part of the migrant population, the Latino/Latinx migrant community, that speak Mayan, contemporary Mayan. So some of the radio stations that are dedicated to Spanish-language radio stations, do have significant programming in Mayan, which I always thought was really cool and interesting. When you drive down the I-5 through the Central Valley where there's a lot of agriculture, or there used to be, it's drying up now, there would be a lot of smaller stations that would be playing programming in Mayan, so it would just be interesting to have that aural mapping, right? Where you're driving through the Central Valley, and you're listening to Mayan, you know, Mayan language, is really interesting.

TYLER: Yeah, like those sonic spheres of language that you can navigate spatially as you move about a geographic region, that you can come into proximity with. ${ }^{42}$ This is making me think of ... what part of Coulthard's arguing in his book is, you know, 'turn away from the politics of recognition and don't seek self-affirmation in the recognition of the Other, or the colonial master,' using the Hegelian slave-master dialectic, or whatever, but instead, to build our own languages, or to rebuild Indigenous languages. As Leanne Simpson says, "I'm not so worried about destroying the master's house, I'm worried about building our own houses." ${ }^{43}$ There's this great line that he draws from Fanon too, that is like "accommodate me as I am, because I'm not accommodating anyone." ${ }^{44}$ That there's a strength in saying 'we don't give a fuck if you hear our language or not, we're going to speak it. You're either going to understand it or you don't. And if you don't understand it, we don't really give a shit because we're going to go on speaking it.'

${ }^{41}$ Arvin, Tuck, and Morrill argue that inclusion can become a deceptive method of social control that "confers a preeminent hierarchy, and inclusion is central to hierarchical power. The project of inclusion can serve to control and absorb dissent rather than allow institutions like feminism and the nation-state to be radically transformed by differing perspectives and goals" (2013, 17). In other words, 'being heard' becomes the illusion of inclusion when it is actually an attempt to pacify, rather than empower.

42 "[. . . ] the resurgent approach to recognition advocated here explicitly eschews the instrumental rationality central to the liberal politics of recognition and instead demands that we enact or practice our political commitments to Indigenous national and women's liberation in the cultural form and content of our struggle itself. Indigenous resurgence is at its core a prefigurative politics-the methods of decolonization prefigure its aims" (Coulthard 2014, 159).

43 "I am not so concerned with how we dismantle the master's house [. . . but how we (re) build our own house, or our own houses" (Simpson, in Coulthard 2014, 148).

44 "Fanon was no longer willing to be recognized on terms imposed by the colonizer: 'Accommodate me as I am, I'm not accommodating anyone”' (Coulthard 2014, 141). 
Whether that's actually a linguistic language, or other cultural practices, or discourses ... you can think of that accommodation in various terms, not just in terms of language, but from many other perspectives too, which I really like a lot.

\{48:54\} [water noises, dripping, car noise in background]

$$
\text { [click of a phone tap] }
$$

[car accelerating rapidly and passing by, fading into the distance]

[footsteps getting louder and closer, beginning to echo as they stomp on a hard asphalt surface]

\{50:05\} MIGUEL: Listening to you walk and then, as I'm walking, having now walked alongside you for part of the way, makes me think of how now I have nostalgia for walking in person with you, that I can relive through listening to you walk at the same time that I'm walking. I think there's a lot to be said there for memory and sound.

TYLER: In a way that our footsteps can now echo each other in a sonic and physical sense.

[footsteps crunch on gravel and leaves]

[sound of large rocks being tossed into the river and splashing, seagulls cry out faintly in the background]

\{51:58\} TYLER: I feel sad now, I don't really want to talk through WhatsApp anymore. It's like having an in-person conversation for that amount of time was such a treat, a gift to be able to hang out with you in person, and now resuming a staggered conversation like this seems disappointing? I just don't feel excited about it anymore, sadly.

TYLER: [loudly] My heart is churning, like the waters spilling over this weir!

[sound of river rushing in the background] 
MIGUEL: Yeah, I feel kinda the same way, like I'm groping for the same sense of personal connectedness that you get just by sitting face to face, that just doesn't exactly happen ... It's funny, I was thinking about this in the context ... I see you by the way, I saw you, I think, you just walked away from the weir. I'm slow, I'm just at the tubing parking lot. I think I see you heading up into the bushes.

TYLER: I am really enjoying how there's like no people on this side of the river. It's more quiet, like what I'm hearing now is based more on my own inner thoughts, hearing my inner auditory imagination, instead of seeing other people or having their sounds interrupt my own aural experience.

\{54:18\} MIGUEL: It makes me think of a conversation I've had, because I've been doing my therapy session by telephone the last couple sessions, and it's made me think about how when you're having a phone call ${ }^{45}$ it's like a disembodied voice that gets kind embodied inside of you, right? And the loss there is that you don't have the other person's body. There's a whole wealth of relational physics that is happening when the other person is physically there that just can't happen, it just does not happen when the other person is not there. And yeah, that's a loss. I don't know how do we ... what do we do when we don't have that ${ }^{46}$ I think it's a whole emotional skillset, an emotional [burps] - excuse me - and relational skill set that's hard to wrap my head around.

TYLER: I'll have to look at the references later, but you're reminding me of writing and research that talks about how digital speech or digital sound actually makes us fundamentally feel in a different way, because there's a physical disconnection from its source. ${ }^{47}$ Also how you were saying about how sound becomes embodied in the listener

45 "Although there has been a vast amount of work done on philosophical problems of language, little has been done concerning the examination of concrete forms of thinking as inner speech considered as a type of auditory imagination. In part, this phenomenon as a phenomenon of a special type of auditory imaginative activity may have been overlooked because of the long tradition of interpretation that maintains a "metaphysical" and "Cartesian" stance toward thought. This tradition takes for granted that thought is disembodied" (Ihde 2007, 134).

46 "What, then, is the form of an embodied auditory imagination? Do I, whenever I turn to 'hearing myself speak, objectify my voice as that of a 'quasi-other'? Or does there lie so close to 'me' a most familiar and this most difficult to elucidate embodied auditory imagination that is the ongoing presence of a dimension of my own thinking, an 'inner speech'?" (Ihde 2007, 121).

47 "[. . . ]in the face-to-face speaking the other is there, embodied, while exceeding his outline-body, but the other is in my focus as there before me face to face. It is in his speaking that he fills the space between us and by it I am auditorily immersed and penetrated as sound 'physically' invades my own body" (Ihde 2007, 79) 
and get's like - [a dull 'whumph'] Whoa fuck! I'm falling down a muddy hill. Is is JeanLuc Nancy who talks about sound as a penetrating force? That sound exchange is a fundamentally affective experience, but also one that can be sensual and erotic, in Audre Lorde's sense of the term. ${ }^{48}$

\{56:43\} MIGUEL: If you look up, the light is hitting the coulees really pretty on the other side right now. I miss you, Tyler!

\section{TYLER: I miss you tooooooo!}

Yeah, this walk [breaths heavily] has been a good opportunity to slow down, which really helps you pay attention and listen to things, instead of moving quickly past them and focusing on where you're going or what else is happening in your life.

MIGUEL: Yeah exactly. I was just watching you through the trees, climbing up the coulee up to the breezeway ... the same hill that's making you all out of breath. [laughter]

\{57:47\} TYLER: Well, I made it to the top, and I'm once again reminded of what an incredible missed opportunity this breezeway is, in terms of having some kind of windpowered aeolian harp or anything of that nature.

MIGUEL: For real! They should just put in some more of the railings that are outside of the library, that like harmonize beautifully and unintentionally. I am walking into the little mini-canyon right now. Listening to the acoustic stillness. ${ }^{49}$ You can just kinda hear the buzzing of the power lines overhead, which I always think is kinda trippy. I like how on windy days they just howl so loud.

Do you think of the unknown as something that is quiet, or something that is loud? Or both? Or neither?

\footnotetext{
48 "Another important way in which the erotic connection functions is the open and fearless underlining of my capacity for joy. In the way my body stretches to music and opens into response, hearkening to its deepest rhythms, so every level upon which I sense also opens to the erotically satisfying experience, whether it is dancing, building a bookcase, writing a poem, examining an idea" (Lorde 1978).

49 "The relation of voice to inner speech and to the pregnant silence of the face gives way ultimately to the open horizon of silence. Here is constituted in effect an ontology of listening and voice in the sense that there is a permanent set of existential possibilities that exceed the strategies seeking to control or deny them" (Ihde 2007, 179).
} 
TYLER: I thought about recording that sound earlier, but my phone was dying. The intense buzz of the power transmission lines. A great example of the flat nature of industrial sounds that just have no peaks and valleys inherent to their sonic signal, they're just a flat, monotonous whine. ${ }^{50}$

$\{59: 33\}$ [footsteps on wet mud, smushy ground]

TYLER: Well, I'm almost at the bus loop, so I'm gonna call Bre to give me a ride home now, but I just want to say how much I appreciate you, Migueltzinta. This has been a great conversation and I'm very thankful for your friendship.

MIGUEL: Awww, Tyler. I really, really appreciate you too. It's really nice to have these really awesome conversations and good feelings, interesting feelings, have good company. I also really appreciate your friendship, and I think we should do this again sometime.

\{1:00:42\} [harmonica plays an approximation of "Oh! Susanna," the background]

\section{END SCENE.}

${ }^{50}$ Schafer notes how sounds in nature typically have more 'peaks and valleys' in their linear representation, while in urban settings sound is typically more 'flat.' Mechanical noises such as factory noise, traffic, air conditioning, etc., become more common after the industrial revolution "introduces the flat line of sound into everyday human experience" $(1977,36)$.

${ }^{51}$ American songwriter Stephen Foster's song, "Oh! Susanna," was originally written as a minstrel song, released in 1848 and performed by various minstrel troupes in blackface. The original lyrics are written in a derogatory mockery of Black southern dialect often used in blackface minstrel performances. Many do not know the history of this song and hear it-and defend it-as, simply, an 'American classic.'

Others do know this history, and uphold the song as a symbol of a proudly racist, American identity. In a similar example from a Canadian context, most Canadian citizens remain unaware that Calixa Lavallée, the composer of "O Canada," himself spent nearly a decade performing as a blackface minstrel before writing the music for the national anthem. For more information, see Harris, R. (2019). Song of a nation: The extraordinary life and times of Calixa Lavallée, the man who wrote O Canada. McClelland \& Stewart: Toronto. 


\section{BIBLIOGRAPHY}

Ahmed, Sara. 2006. "Sexual Orientation." In Queer Phenomenology: Orientations, Objects, Others, 65-107. Durham: Duke University Press.

Arvin, Maile, Tuck, Eve, and Morrill, Angie. 2013. "Decolonizing feminism: Challenging connections between settler colonialism and heteropatriarchy." Feminist Formations, (25)1, 8-34.

Augoyard, J.F. 1995. Sonic Experience: A Guide to Everyday Sounds. McGill-Queen's University Press.

Barthes, Roland. 1991. The Responsibility of Forms: Critical Essays on Music, Art, and Representation. Berkeley: University of California Press.

Blesser, B. and Salter, L.R. 2006. Spaces Speak, Are You Listening? Experiencing Aural Architecture. MIT Press.

Bruised Head, Mike. "Obtaining Indigenous Knowledge: Really Knowing from Place," YouTube video, 51:11, Nov 15th 2018, University of Alberta. https://www.youtube.com/watch?v=uXIsOWWks6Y

Coulthard, Glen Sean. 2014. Red Skin, White Masks: Rejecting the Colonial Politics of Recognition. University of Minnesota Press.

Cruikshank, Julie. 2005. Do Glaciers Listen?: Local Knowledge, Colonial Encounters, and Social Imagination. UBC Press.

Francis, Margot. 2011. Creative Subversions: Whiteness, Indigeneity, and the National Imaginary. UBC Press.

Foy, G.M. 2010. Zero Decibels: The Quest for Absolute Silence. Scribner.

Glennie, Evelyn. 2015. "Hearing Essay.” Last modified January 1, 2015. https://www.evelyn.co.uk/hearing-essay/

Harris, R. 2019. Song of a nation: The extraordinary life and times of Calixa Lavallee, the man who wrote O Canada. McClelland \& Stewart: Toronto.

Ihde, Don. 2007. Listening and voice: Phenomenologies of Sound (2nd ed.). Albany: State University of New York Press.

Lorde, Audre. 1978. Uses of the Erotic: The Erotic as Power. Out \& Out Books.

Rifkin, Mark. 2014. Settler Common Sense: Queerness and Everyday Colonialism in the American Renaissance. University of Minnesota Press. 
Robinson, Dylan. 2020. Hungry Listening: Resonant Theory for Indigenous Sound Studies. University of Minnesota Press.

Schafer, R. Murray. 1977. The Soundscape: Our Sonic Environment and the Tuning of the World. Rochester, Vt.: Destiny Books.

Schmidt, L.E. 2003. "Hearing Loss." In The Auditory Culture Reader, Bull, M. and Back, L. (eds). Bloomsbury.

Simpson, Leanne Betasamosake. 2014. "Land as Pedagogy." In Decolonization: Indigeneity, Education, and Society, 3(3), 1-25.

Stoever, Jennifer Lynn. 2016. The Sonic Color Line: Race and the Cultural Politics of Listening. New York University Press.

Truax, Barry. 1984. Acoustic Communication. Ablex Publishing: New Jersey.

Tuck, Eve, and Yang, K. Wayne. 2012. "Decolonization is Not a Metaphor."

Decolonization: Indigeneity, Education, and Society 1(1), 1-40.

Wolfe, Patrick. 2006. "Settler colonialism and the elimination of the native." Journal of Genocide Research, 8(4), 387-409. 